\title{
Adjuvant effects of chemotherapeutics and Metformin on MFE-319 endometrial carcinoma cell line
}

\author{
Isil AydemiR ${ }^{1)}$, Elgin Turkoz Uluer ${ }^{2)}$, Oya Korkmaz ${ }^{3)}$, MeHMet Ibrahim Tuglu2), SeVinc Inan ${ }^{4)}$ \\ 1) Department of Histology and Embryology, Faculty of Medicine, Nigde Omer Halisdemir University, Turkey \\ 2) Department of Histology and Embryology, Faculty of Medicine, Manisa Celal Bayar University, Turkey \\ 3) Department of Histology and Embryology, Faculty of Medicine, Istanbul Medipol University, Turkey \\ ${ }^{4)}$ Department of Histology and Embryology, Faculty of Medicine, Izmir University of Economics, Turkey
}

\begin{abstract}
We aimed to investigate the cytotoxicity of Metformin, Cisplatin, and Paclitaxel on MFE-319 endometrial carcinoma cell line using 3-(4,5dimethylthiazol-2-yl)-2,5-diphenyltetrazolium bromide (MTT) and immunocytochemistry assays. Half maximal inhibitory concentration (IC $\left.\mathrm{C}_{50}\right)$ doses of three drugs alone and in the dual combinations were applied to the cells. Immunocytochemical method was performed for the cell survival and for phosphatidylinositol 3-kinase (PI3K), phosphorylated extracellular regulated kinases (pErk)-1/2, Akt-1, phosphorylated Akt (pAkt)-1/2/3 cell growth markers and angiogenic vascular endothelial growth factor (VEGF). Immunoreactivities were evaluated using $H$-score and analyzed using the one-way analysis of variance (ANOVA) test for statistics. It was found that these drugs caused a decrease in the immunoreactivities of these markers. Particularly, dual combination of Paclitaxel and Cisplatin decreased the immunoreactivities of PI3K, pErk-1/2, Akt-1, and pAkt-1/2/3. Cisplatin and Paclitaxel were more effective than Metformin; on the other hand, Metformin has been shown to enhance the efficacy of these two drugs. In vitro or in vivo further studies are needed to investigate the efficacy of these three drugs via PI3K/Akt signal pathway.
\end{abstract}

Keywords: Cisplatin, endometrial carcinoma, Metformin, PI3K/Akt, Paclitaxel.

\section{口 Introduction}

Endometrial carcinoma (EC) is one of the most common cancers and the sixth leading cause of cancer incidence in women worldwide $[1,2]$. It is reported that EC has different histological subtypes, such as adenocarcinoma and sarcoma. Type 1 endometrial tumors are estrogen receptor and progesterone receptor $(\mathrm{ER} / \mathrm{PR})$ positive, whereas type 2 is negative for these receptors. Because of negativities for ER/PR, type 2 is an aggressive form of $\mathrm{EC}$ and has poor prognosis. The risk factors for EC are atypical endometrial hyperplasia, hypertension, diabetes, and obesity. The control of these diseases plays an important role in delaying the progression of cancer and in the treatment [3].

The treatment of EC contains hysterectomy, chemotherapy, or radiation. The different chemotherapeutic agents are used in the treatment of EC. Especially the combinations of Doxorubicin, Cisplatin, Cyclophosphamide, Paclitaxel, Carboplatin are used clinically [4-6]. However, it has been indicated that Metformin, an antidiabetic oral agent, has antiproliferative effect on tumor cells in vitro and in vivo conditions. Previous studies have been drawing attention to the relationship between the Metformin and prevention of cancer in diabetic patients; it has also been shown to be effective in many diseases, such as polycystic ovarian syndrome, steatohepatitis, cardiovascular diseases, and human immunodeficiency virus (HIV)-associated metabolic abnormalities [7-11]. The preclinical and in vitro studies reported that Metformin has an antitumor effect on many types of cancer, breast, prostate, hepatocellular and endometrial cancers [7]. Therefore, it is important to define the effective dose for the treatment strategy, because the responses to the chemotherapeutic agents are short duration and differs among women [12]. The status of estrogen dependence and molecular factors ascertain the response to the treatment.

The pathway of phosphatidylinositol 3-kinase (PI3K)/ Akt/mechanistic target of rapamycin (mTOR) plays a substantial role in cell survival, proliferation, differentiation, metastasis, and apoptosis [13]. Overexpression of PI3K causes cells to have cancer characteristics and uncontrolled proliferation. In this pathway, Akt inhibits the apoptosis by inactivating the antiapoptotic proteins, such as Bad, and increasing the phosphorylation of the proapoptotic protein Bcl-2 associated X (Bax). mTOR triggers the Akt/mTOR signaling pathway by raising the translation of protein through Akt activation [14, 15]. Also, the extracellular regulated kinases (Erk) pathway is important in cancer progress, via cell proliferation, differentiation, apoptosis, migration, and invasion. Previous experiments showed that the proliferation and invasion of tumor cells were decreased by blocking of Erk/mitogen-activated protein kinase (MAPK) signaling in colorectal and endometrial cancer $[16,17]$. Besides the cell proliferation and invasion, the angiogenesis requires some regulatory factors, such as vascular endothelial growth factor (VEGF), fibroblast growth factor (FGF), and transforming growth factor (TGF). VEGF enhances the angiogenesis by activating vascular endothelial cells and circulating monocytes. It also induces

This is an open-access article distributed under the terms of a Creative Commons Attribution-NonCommercial-ShareAlike 4.0 International Public License, which permits unrestricted use, adaptation, distribution and reproduction in any medium, non-commercially, provided the new creations are licensed under identical terms as the original work and the original work is properly cited. 
the formation of antiapoptotic proteins, Bcl-2 and A1 in cells and provides long-term survival of endothelial cells. VEGF prevents differentiation of monocytes to endotheliumlike cells [18]. It is stated that VEGF is expressed in most of the EC cases and it is involved in deep myometrial invasion [19].

\section{Aim}

The suppression of angiogenesis and cell proliferation is an important goal in the EC treatment. However, determination of the signaling molecules that play a role in EC will be useful in the management of the cure protocol. The aim of the present study was to investigate the effects of Cisplatin, Paclitaxel, and Metformin on the MFE-319 EC cell line $(\mathrm{ER}+/ \mathrm{PR}+)[20]$ as single agents and in dual combinations with each other in vitro condition via PI3K/Akt signal pathway and VEGF.

\section{ㅁ Materials and Methods}

\section{Cell culture}

The MFE-319 EC cell line was grown in 40\% Roswell Park Memorial Institute (RPMI)-1640 medium, 40\% minimum essential medium (MEM, with Earle's salts) and $20 \%$ fetal bovine serum (FBS, heat inactivated) at $37^{\circ} \mathrm{C}$ in $5 \% \mathrm{CO}_{2}$ in a humidified atmosphere. The medium was changed every two days. The cells were morphologically examined using an inverted microscope and photographs of the cells were taken.

\section{Cytotoxicity assay}

The cytotoxicity of Paclitaxel, Cisplatin and Metformin was measured using 3-(4,5-dimethylthiazol-2-yl)-2,5diphenyltetrazolium bromide (MTT) assay. MFE-319 cells were passaged into 96 -well $\left(2.5 \times 10^{5}\right.$ cells/well $)$ plates and seeded for four days before drug treatment. The doubling time of MFE-319 cells were 100 hours. After incubation, the cells were treated with an increasing concentration of Paclitaxel $(0,0.1,1,10,30,100 \mu \mathrm{g} / \mathrm{mL})$, Cisplatin $(0,1$, $10,100,500,1000 \mu \mathrm{M})$ and Metformin $(0,0.1,1,10,30$, $100 \mathrm{mM}$ ) drugs for 24 hours. Then, the medium containing drug was discharged and fresh medium $(100 \mu \mathrm{L})$ with $10 \mu \mathrm{L}$ MTT ( $5 \mathrm{mg} / \mathrm{mL}$ in distilled water) was added. The incubation with MTT performed at $37^{\circ} \mathrm{C}$ for four hours. The medium containing MTT was removed and $100 \mu \mathrm{L}$ of dimethyl sulfoxide (DMSO) was added to each well. The absorbance was measured at a wavelength of $570 \mathrm{~nm}$ using an ultraviolet-visible (UV-VIS) spectrophotometer multiplate reader [21]. The half maximal inhibitory concentration $\left(\mathrm{IC}_{50}\right)$ of agents were calculated using absorbance values by GraphPad Software.

\section{Drug treatments}

MFE-319 cells were placed in 12-well plates at a density of $2.5 \times 10^{5}$ cells/well and allowed to grow under routine conditions for four days. The cells were randomly divided into seven groups. These were the control (no drug treatment), Paclitaxel ( $\mathrm{IC}_{50}$ dose, $1.5 \mu \mathrm{g} / \mathrm{mL}$ ), Cisplatin $\left(\mathrm{IC}_{50}\right.$ dose, $\left.350 \mu \mathrm{M}\right)$, Metformin $\left(\mathrm{IC}_{50}\right.$ dose, $20 \mathrm{mM}$ ) and Paclitaxel + Cisplatin, Paclitaxel + Metformin and Cisplatin + Metformin. The cells were exposed to these drugs for 24 hours.

\section{Immunocytochemistry}

After drug treatments, the medium was removed, and cells were rinsed with sterilized phosphate-buffered saline (PBS) and fixed with 4\% paraformaldehyde in PBS at $+4^{\circ} \mathrm{C}$ for 30 minutes. Then, the cells were washed in PBS three times for 5 minutes. Permeabilization was performed with $0.1 \%$ Triton $\mathrm{X}-100$ in PBS at $+4^{\circ} \mathrm{C}$ for 15 minutes. Endogenous peroxidase activity was inhibited using 3\% hydrogen peroxide for 5 minutes at room temperature. Cells were then washed with PBS and incubated with primary antibodies: anti-Akt-1, anti-pAkt-1/2/3, anti-pErk-1/2, anti$\mathrm{PI} 3 \mathrm{~K}$ and anti-VEGF at $+4^{\circ} \mathrm{C}$ overnight. After removal of the primary antibodies, cells were washed with PBS and treated with biotinylated secondary antibodies and peroxidase-conjugated Streptavidin. Cells were then incubated with 3,3'-Diaminobenzidine (DAB)/hydrogen peroxide and counterstaining was performed using Mayer's Hematoxylin. Stained cells were mounted with mounting medium and were photographed by a light microscope (inverted fluorescence phase microscope). Control samples were processed in an identical manner, but the primary antibody was omitted. Three observers blinded to experiments evaluated the staining scores independently. The immunocytochemical staining was evaluated using $H$-score method. For this purpose, the intensities of immunocytochemical staining were evaluated as weak $(+)$, moderate $(++)$ and strong $(+++)$ respectively, and the cells were counted in three different microscopic areas for each intensity. The respective score was then calculated using the formula $H$-score $=\sum P_{i}$ (intensity of staining +1 ). $P_{i}$ is the percentage of stained cells for intensity, varying from $0 \%$ to $100 \%$. The staining procedure was repeated three times and the $H$-score was evaluated by at least two investigators independently [22].

\section{Statistical analysis}

The data was statistically expressed as mean values (mean \pm standard deviation) and were analyzed using repeated measures of the one-way analysis of variance (ANOVA) test. The Tukey-Kramer multiple comparisons test was used to determine differences amongst the mean values. Values for $p<0.05$ were considered significant [22].

\section{Results}

\section{Cytotoxicity assay}

To confirm the cytotoxic effects of Paclitaxel, Cisplatin and Metformin, MTT assay was performed with Metformin $(0,0.1,1,10,30,100 \mathrm{mM})$, Paclitaxel $(0,0.1,1,10,30$, $100 \mu \mathrm{g} / \mathrm{mL})$ and Cisplatin $(0,1,10,100,500,1000 \mu \mathrm{M})$ and for 24 hours. The cell proliferation was quenched with increasing concentrations of agents. With the administration of Metformin, the cell survival was $85 \pm 7.1 \%$ at $0.1 \mathrm{mM}$, $83 \pm 8.0 \%$ at $1 \mathrm{mM}, 70 \pm 6.0 \%$ at $10 \mathrm{mM}, 51 \pm 5.5 \%$ at $30 \mathrm{mM}$ and $42 \pm 5.1 \%$ at $100 \mathrm{mM}$, whereas the survival was $96 \pm 9.5 \%$ in the control group $(0 \mathrm{mM})$. The viability rates in the presence of Paclitaxel were $82 \pm 7.5 \%$ at $0.1 \mu \mathrm{g} / \mathrm{mL}, 65 \pm 7.0 \%$ at $1 \mu \mathrm{g} / \mathrm{mL}, 60 \pm 6.7 \%$ at $10 \mu \mathrm{g} / \mathrm{mL}, 51 \pm 6.0 \%$ at $30 \mu \mathrm{g} / \mathrm{mL}$ and $42 \pm 6.2 \%$ at $100 \mu \mathrm{g} / \mathrm{mL}$. It was determined that Cisplatin had a more toxic effect at $500 \mathrm{mM}(42 \pm 6.0 \%)$ and $1000 \mathrm{mM}$ $(39 \pm 6.1 \%)$ doses compared to other doses $(0,1,10$ and 
$100 \mathrm{mM})(* * * p<0.001) . \mathrm{IC}_{50}$ doses of agents were calculated as $1.5 \mu \mathrm{g} / \mathrm{mL}$ Paclitaxel, $350 \mu \mathrm{M}$ Cisplatin and $20 \mathrm{mM}$ Metformin (Figure 1, A-C).
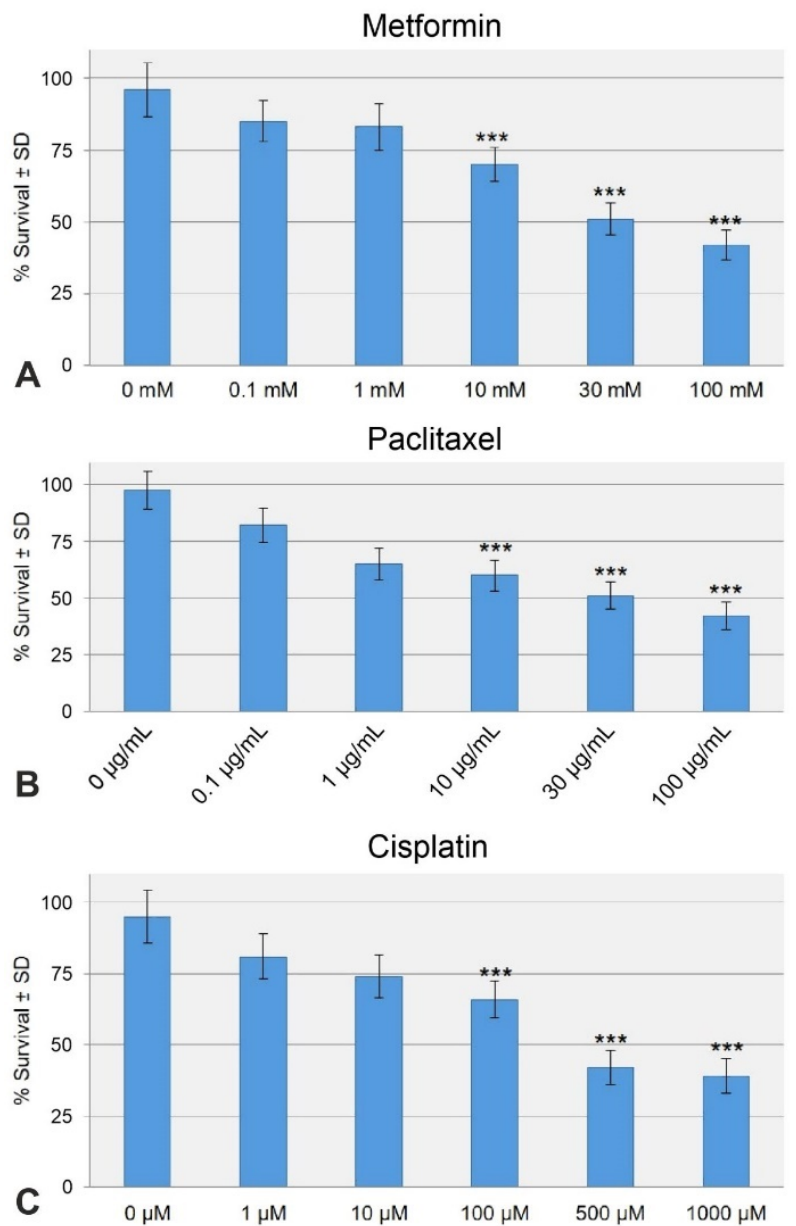

Figure 1 - The survival of MFE-319 endometrial carcinoma cells with Metformin (A), Paclitaxel (B) and Cisplatin (C) for 24 hours was analyzed using MTT assay. Percentage of cell survival was analyzed using the one-way ANOVA test with Tukey-Kramer multiple comparisons test. ANOVA: Analysis of variance; MTT: 3-(4,5-Dimethylthiazol-2-yl)-2,5-diphenyltetrazolium bromide; SD: Standard deviation.

\section{Immunocytochemistry}

For the immunocytochemical detection of Akt-1, pAkt1/2/3, pErk-1/2, PI3K and VEGF in MFE-319 EC cells, single and dual combinations of Paclitaxel, Cisplatin and Metformin were administered to the cells. The $H$-score evaluations were shown in Figures 2 and 4. In the control and Metformin groups, the immunoreactivities of Akt-1, pAkt-1/2/3, pErk-1/2, PI3K and VEGF were greater than the Paclitaxel and Cisplatin groups (Figure 2), whereas they were significantly decreased in the Paclitaxel and Cisplatin groups $(* * * p<0.001)$. The distribution of Akt-1 was reduced by administration of Paclitaxel (136 \pm 12.4$)$ and Cisplatin (122 \pm 11.5$)$ compared to control (225 \pm 12.8$)$ and Metformin (228 \pm 12.0$)$ groups. The $H$-score values of pAkt-1-2-3 were $230 \pm 11.9$ in the control group, $233 \pm 12.7$ in the Metformin group, $140 \pm 11.4$ in the Paclitaxel group and $133 \pm 10.6$ in the Cisplatin group. When the immunoreactivity of pErk-1/2 was evaluated, there was no significant difference between the control (222 \pm 10.9$)$ and Metformin
$(236 \pm 13.2)$ groups. Also, the level of PI3K was diminished with Paclitaxel $(125 \pm 10.1)$ and Cisplatin (118 \pm 10.2$)$ applications in comparison with the control $(215 \pm 11.0)$ and Metformin (221 \pm 12.0$)$ groups (Figure 2).

Cisplatin especially decreased the immunoreactivities of PI3K, pErk-1/2, Akt-1, and pAkt-1/2/3 $(* * * p<0.001)$. VEGF immunostaining was the highest in the control group (295 \pm 13.0$)$ and decreased with Cisplatin (160 \pm 12.1$)$ application. The applications of Paclitaxel and Cisplatin caused a decrease in the markers of cell survival and angiogenesis (Figure 3). It was ascertained that these drugs caused a decrease in the immunoreactivities in the following order of potency: Cisplatin $>$ Paclitaxel $>$ Metformin.

With the dual combinations of drugs, Paclitaxel + Cisplatin prominently reduced the immunoreactivities of Akt-1 (122 \pm 12.3$)$, pAkt-1/2/3 (133 \pm 13.0$)$, pErk-1/2 $(124 \pm 12.4)$, PI $3 \mathrm{~K}(118 \pm 11.8)$ and VEGF $(160 \pm 12.1)$ when compared to the other combinations $(* * * p<0.001)$. Also, Metformin and Paclitaxel were found to have synergistic effects on MFE-319 cells (Figure 4). The combination of Metformin and Paclitaxel diminished the distributions of Akt-1 (136 \pm 12.4$)$, pAkt-1/2/3 (145 \pm 12.8$)$, pErk-1/2 $(135 \pm 12.2)$, PI3K $(128 \pm 12.0)$ and VEGF (230 \pm 13.5$)$. The combination of Metformin and Cisplatin has no statistically significant effect on these markers $(p>0.05)$ in comparison with the other combinations. The dual combinations of these drugs have the inhibitor effects in the immunoreactivities in the following order of potency: Paclitaxel + Cisplatin $>$ Metformin + Paclitaxel $>$ Metformin + Cisplatin (Figure 4).

\section{ㅁ Discussions}

We ascertained that there was a significant difference in the immunocytochemical reactivities of Akt-1, pAkt$1 / 2 / 3$, pErk-1/2, PI3K and VEGF in MFE-319 cells in the Cisplatin group and Cisplatin + Paclitaxel group compared to the other groups. There was a prominent decrease in these markers in the presence of dual combination of Paclitaxel and Cisplatin whereas there was no statistical significance between the control and Metformin groups. The current study claimed that Metformin caused cytotoxicity in MFE-319 cells, but it has no inhibition effect on Akt-1, pAkt-1/2/3, pErk-1/2, PI3K and VEGF in MFE319 cells in vitro conditions.

Paclitaxel is an anti-microtubule agent. It blocks the formation of microtubules consisting of tubulin dimers and stabilizes the microtubules by preventing depolymerization and thus mitosis is inhibited. This characteristic of Paclitaxel is important in terms of the preventing cell proliferation in cancer cases. In vivo and in vitro studies showed the antiproliferative effect of Paclitaxel in EC cells. In UTEC-1 endometrial cells, Paclitaxel caused $72 \%$ of growth inhibition. The $73 \%$ of growth inhibition occurred with the combination of Paclitaxel and Carboplatin, whereas Carboplatin caused 54\% of growth inhibition. Paclitaxel was found to show synergistic effect with Carboplatin [12]. Similarly, Paclitaxel has a cytotoxic effect on Ishikawa cells, by increasing the expression of caspase- 3 and decreasing the levels of VEGF and proliferating cell nuclear antigen (PCNA) [23]. 


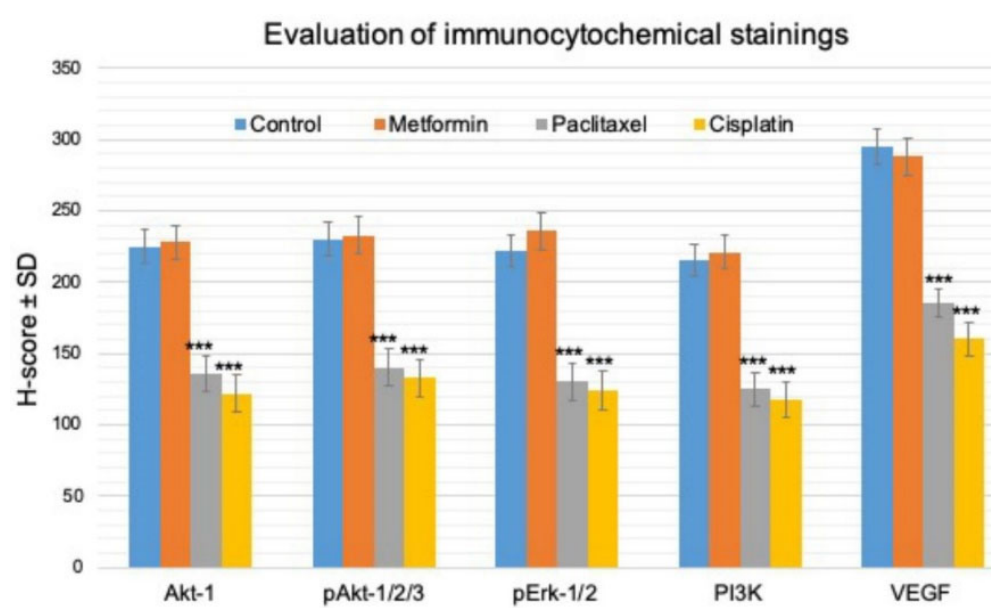

Figure 2 - The H-score analysis of immunocytochemical staining of Akt-1, pAkt-1/2/3, pErk-1/2, PI3K and VEGF in MFE-319 endometrial carcinoma cells after application with Paclitaxel, Cisplatin and Metformin for 24 hours. pAkt1/2/3: Phosphorylated Akt-1/2/3; pErk-1/2: Phosphorylated extracellular regulated kinases-1/2; PI3K: Phosphatidylinositol 3-kinase; SD: Standard deviation; VEGF: Vascular endothelial growth factor.

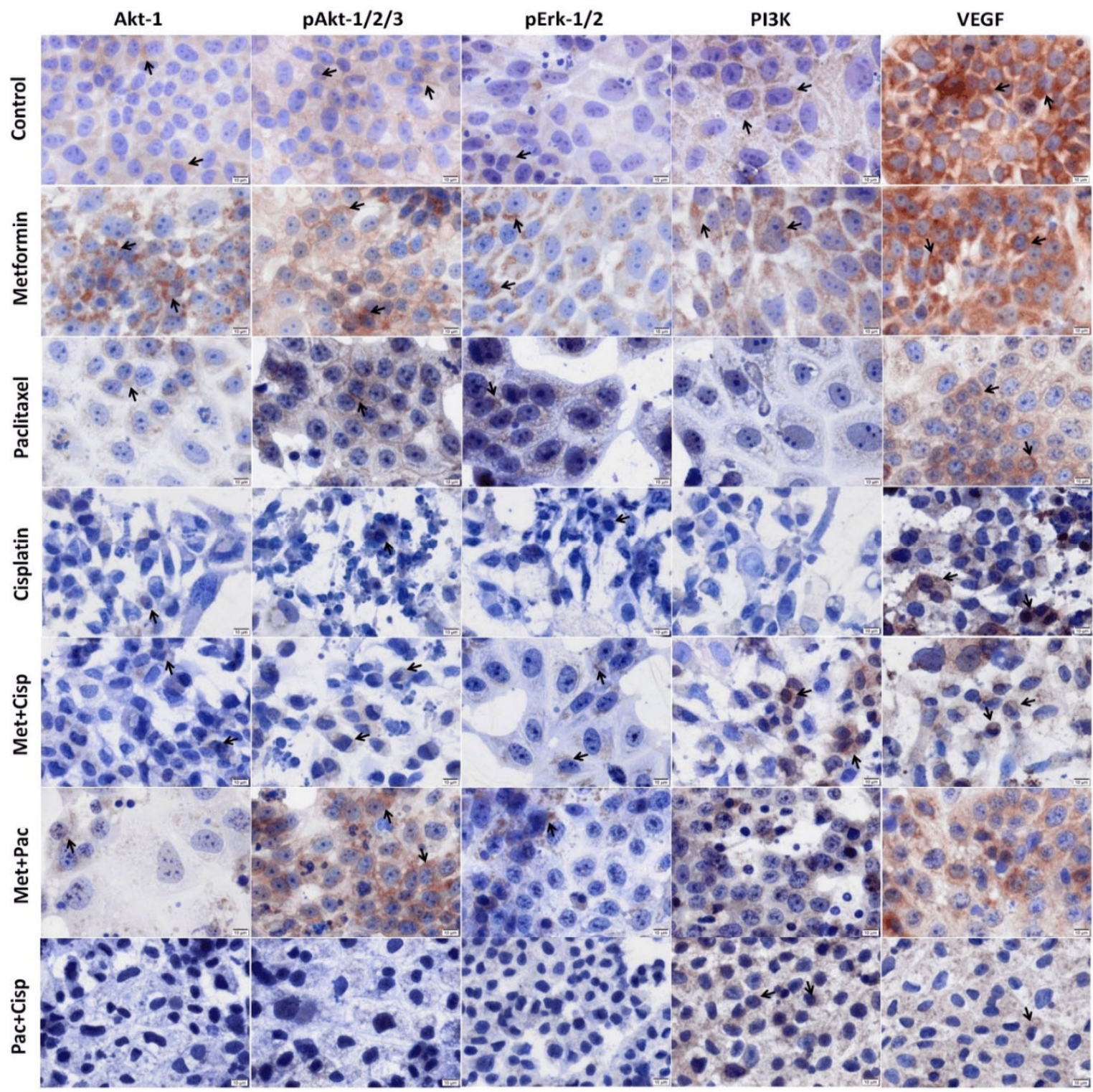

Figure 3 - The immunocytochemical staining of Akt-1, pAkt-1/2/3, pErk-1/2, PI3K and VEGF in MFE-319 endometrial carcinoma cells after application with Paclitaxel (Pac), Cisplatin (Cisp), Metformin (Met), and dual combinations of drugs for 24 hours. Arrows: Immunopositive cells. Scale bars: 10 um. pAkt-1/2/3: Phosphorylated Akt-1/2/3; pErk-1/2: Phosphorylated extracellular regulated kinases-1/2; PI3K: Phosphatidylinositol 3-kinase; VEGF: Vascular endothelial growth factor. 


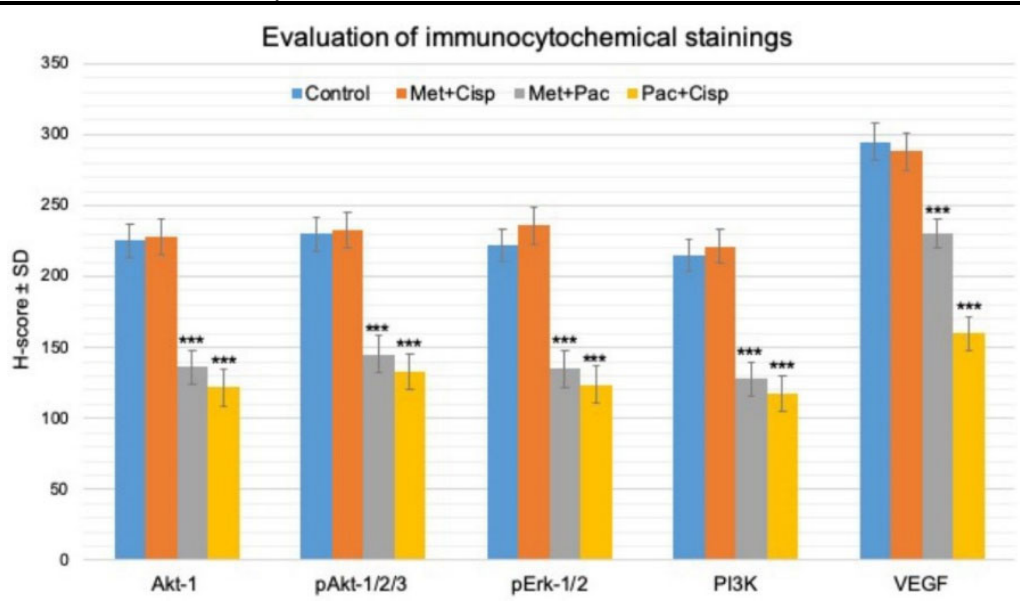

Figure 4 - The H-score analysis of immunocytochemical staining of Akt-1, pAkt-1/2/3, pErk-1/2, PI3K and VEGF in MFE-319 endometrial carcinoma cells after application with the dual combinations of Paclitaxel (Pac), Cisplatin (Cisp) and Metformin (Met) for 24 hours. pAkt-1/2/3: Phosphorylated Akt-1/2/3; pErk-1/2: Phosphorylated extracellular regulated kinases-1/2; PI3K: Phosphatidylinositol 3-kinase; SD: Standard deviation; VEGF: Vascular endothelial growth factor.

In patients with $\mathrm{EC}$, increased expression of angiogenic markers, such as VEGF, are related to the progression or metastasis of carcinoma cells. According to data from M. D. Anderson, overexpression of VEGF was detected in $56 \%$ of endometrial tumors [24]. Besides VEGF, $\mathrm{PI} 3 \mathrm{~K} / \mathrm{Akt} / \mathrm{mTOR}$ pathway plays an important role in tumor cell survival, angiogenesis, and metastasis mechanism; therewithal, the increase in PI3K expression stimulates proliferation in tumor cells. Akt plays a role in the suppression of apoptosis $[14,15]$. In the present study, the proliferation of MFE-319 endometrial cells were suppressed markedly by Paclitaxel, and we determined that there was a significant diminished expression of Akt-1, pAkt-1/2/3, pErk-1/2, PI3K and VEGF. Dinkic et al. (2017) stated a similar cytotoxic effect of Paclitaxel in HEC-1A and AN3CA EC cells [25].

Recent studies have reported that Metformin, an antidiabetic drug used in the cure of type 2 diabetes mellitus, has an antiproliferative effect on several cancer types. It has been reported that Metformin blocks the cell cycle and triggers apoptosis in tumor cells [26-29]. Also, it has been indicated that Metformin exerts its antitumorigenic effect by inhibiting gluconeogenesis in the liver and by down-regulating signal pathways such as Erk and mTOR [30-32]. Therefore, signaling pathways that play a role in cancer progression and proliferation are emphasized. In a previous study, biopsy samples were taken from women diagnosed with EC and who were treated with or without Metformin. The biopsy samples were immunohistochemically stained. In the group of Metformin treatment, the immunoreactivities of Ki-67, PI3K, pAkt, phosphorylated ribosomal S6 kinase 1 (p-S6K1), and phosphorylated 4Ebinding protein ( $\mathrm{p}-4 \mathrm{E}-\mathrm{BP} 1)$ significantly decreased compared to non-treatment of Metformin [29]. It has been observed that meta-analysis studies support these findings. The effect of Metformin usage in women with EC has been discussed in many studies. It has been found that the life expectancy of EC patients was increased with the use of Metformin, compared to non-Metformin users. Also, it was seen that the proliferation markers, such as Ki-67, phosphorylated adenosine monophosphate (AMP)-activated protein kinase (pAMPK), phosphorylated S6 (p-S6), pAkt, p-4E-BP1 were reduced in women with EC who intake Metformin [33]. In a similar study, 50\% reduction in cell proliferation markers was detected when women diagnosed with EC were given an increasing dose of Metformin $(750,1500$ and $2250 \mathrm{mg} /$ day) for four to six weeks. In tumor samples from patients, it was determined that the levels of phospho-ribosomal protein S6, pErk-1/2, cyclin D1 decreased after Metformin uptake [34]. Metformin was found to be toxic for ECC-1 and Ishikawa EC cell lines. The $\mathrm{IC}_{50}$ doses were approximately $1 \mathrm{mM}$ for both cells for 72 hours. By the Western immunoblotting assay, it has been shown that AMPK was increased and p-S6 was decreased in the presence of Metformin. Based on these findings, researchers concluded that Metformin has an antiproliferative effect by inhibiting the mTOR signaling pathway [26]. In another study, the $5 \mathrm{mM}$ Metformin dose caused cell death in both HEC-1-A and Ishikawa cell lines by suppressing the mTOR signaling. It was suggested that the inhibitor effect occurred by inhibiting the phosphorylated ribosomal protein S6 kinase $\beta$-1 (p70S6K) and activating the AMPK molecule [35]. In our experiment, we used MFE-319 EC cell line, and found that Metformin was toxic on MFE-319 cells via MTT assay ( $\mathrm{IC}_{50}$ dose, $20 \mathrm{mM}$ ). But there was no inhibitory effect on the PI3K/Akt/mTOR signal pathway. This finding suggested that Metformin may have exerted its toxic effect through another signaling pathway in MFE-319 cells.

Cisplatin, another chemotherapeutic agent, is used clinically for the cancer treatments. It targets deoxyribonucleic acid (DNA) replication and interferes the cell proliferation in tumor cells, such as cervical, ovarian, testicular, lung, bladder head and neck cancers [36, 37]. It was also found that it accumulates in the cell organelles and cytosol, such as lysosomes, mitochondria, endoplasmic reticulum, and nucleus, and leads the cell to death in tumor cells. It is claimed that Cisplatin disrupts the structure and function of organelles, at the same time it alters the protein structures; thus, it causes the cell death [37]. Like other two agents, Paclitaxel and Metformin, Cisplatin suppresses EC cells in vivo and in vitro conditions. In vitro conditions, 
Cisplatin has been shown to induce cell death through autophagy in EC cells. It has been stated that the increased doses of Cisplatin $(10,20,40,80 \mu \mathrm{g} / \mathrm{mL})$ caused the suppression of cell proliferation in EC cells. Also, at $20 \mu \mathrm{g} / \mathrm{mL}$, the expression levels of pAkt-1, PI3K, phosphorylated mTOR ( $\mathrm{p}-\mathrm{mTOR}$ ) was reduced notably [38]. It was indicated that $1 \mathrm{mM}$ of Cisplatin inhibited the cell proliferation in HeLa cervical cells and Ishikawa EC cells by $50 \%$ in vitro conditions. Beside the inhibition of cell proliferation, it was determined that it caused changes in both cell membranes by using atomic force microscopy quantitatively. After 24 hours of Cisplatin application, the size of both cells was decreased, whereas the membranes of HeLa cells were found to be rougher than the Ishikawa cells [39]. In our study, we found that cisplatin caused cell death in MFE-319 cells by inhibiting the PI3K/Akt/mTOR signaling.

In addition to these studies which the drugs were administered alone, there were also combination dual drug trials in both clinical and experimental studies. In a phase I study, for 28 days, different types of cancer patients (colorectal, sarcoma, endometrial, ovarian, and other types) were given $25 \mathrm{mg}$ of weekly Temsirolimus and Metformin in increasing doses $(500,1000,1500$ and $2000 \mathrm{mg} /$ day), and the synergistic effect between these two drugs was evaluated. It was observed that Metformin enhanced the efficacy of Temsirolimus, another chemotherapeutic agent that have targeted mTOR [40]. In HO8910 human ovarian cancer cells treated with Metformin, the cell proliferation was reduced dose dependent manner $(0.5,1,5 \mathrm{mM})$, whereas Metformin combined with Cisplatin $(5 \mu \mathrm{M})$ markedly inhibited the cell proliferation and also the expressions of pErk-1/2, VEGF and VEGF receptor 2 (VEGFR2) messenger ribonucleic acid (mRNA). These two drugs showed a synergistic effect, and their toxic efficiencies were increased [41]. Asik et al. reported that the dual administration of Metformin $(4 \mu \mathrm{M})$ and Paclitaxel $(34 \mathrm{nM})$ caused an alteration in the 86 genes that have a role in leukemia in HL-60 human promyelocytic leukemia cell line. It has been stated that Metformin and Paclitaxel decreased the cancer cell proliferation markers, such as Akt-1, MAPK14, cluster of differentiation 40 ligand (CD40LG), while there was an increase in the molecules, apoptotic protease activating factor 1 (APAF1), caspase-1, $-4,-5,-8$ and -14 , that played role in apoptosis [42]. In MFE-319 cells, there was no significant difference immunocytochemically in the group of Metformin and Cisplatin. This finding suggested that MFE-319 cells showed resistance to these two drugs. Concurrently, Metformin enhanced the antitumor activity of Paclitaxel [43, 44]. We also obtained similar results with this finding in our study.

In summary, our experiment demonstrate that the combination of Paclitaxel and Cisplatin has diminished the distributions of Akt-1, pAkt-1/2/3, pErk-1/2, PI3K and VEGF, according to immunocytochemical staining. In order to understand the pathways through which these drugs exert their cytotoxic effects, the other signaling molecules should also be investigated.

\section{a Conclusions}

In our experiment, when drugs were administered alone to MFE-319 cells, the toxicities of Cisplatin and Paclitaxel were higher than Metformin. In the dual combinations, Metformin increased the cytotoxicity of Paclitaxel on the MFE-319 cells. Also, Paclitaxel showed a synergistic effect by improving the activity of Cisplatin. The inhibition effect of Paclitaxel + Cisplatin administration on Akt-1, pAkt-1/2/3, pErk-1/2, PI3K and VEGF was higher than Metformin + Paclitaxel and Metformin + Cisplatin groups. These findings belong to our experiment of cell culture conditions and therefore further studies of in vivo cancer model are needed to determine the efficacy of drugs.

\section{Conflict of interests}

The authors declare no conflict of interests.

\section{Funding}

This research received no specific grant from any funding agency in the public, commercial, or not-forprofit sector.

\section{References}

[1] Chen Q, Gao Q, Chen K, Wang Y, Chen L, Li XU. Curcumin suppresses migration and invasion of human endometrial carcinoma cells. Oncol Lett, 2015, 10(3):1297-1302. https:// doi.org/10.3892/ol.2015.3478 PMID: 26622667 PMCID: PMC4533742

[2] Wan J, Yin Y, Zhao M, Shen F, Chen M, Chen Q. The positivity of G-protein-coupled receptor-30 (GPR 30), an alternative estrogen receptor is not different between type 1 and type 2 endometrial cancer. Oncotarget, 2017, 8(53):90897-90904. https://doi.org/10.18632/oncotarget.18545 PMID: 29207611 PMCID: PMC5710892

[3] Braun MM, Overbeek-Wager EA, Grumbo RJ. Diagnosis and management of endometrial cancer. Am Fam Physician, 2016, 93(6):468-474. PMID: 26977831

[4] Barrena Medel NI, Bansal S, Miller DS, Wright JD, Herzog TJ. Pharmacotherapy of endometrial cancer. Expert Opin Pharmacother, 2009, 10(12):1939-1951. https://doi.org/10.1517/ 14656560903061291 PMID: 19586421

[5] Ray M, Fleming G. Management of advanced-stage and recurrent endometrial cancer. Semin Oncol, 2009, 36(2):145-154. https:// doi.org/10.1053/j.seminoncol.2008.12.006 PMID: 19332249

[6] Vergote I, Debruyne P, Kridelka F, Berteloot P, Amant F, Honhon B, Lybaert W, Leunen K, Geldhof K, Verhoeven D, Forget F, Vuylsteke P, D'Hondt L, Huizing M, Van den Bulck H, Laenen A. Phase II study of weekly paclitaxel/carboplatin in combination with prophylactic G-CSF in the treatment of gynecologic cancers: a study in 108 patients by the Belgian Gynaecological Oncology Group. Gynecol Oncol, 2015, 138(2): 278-284. https://doi.org/10.1016/j.ygyno.2015.05.042 PMID: 26049123

[7] Hajjar J, Habra MA, Naing A. Metformin: an old drug with new potential. Expert Opin Investig Drugs, 2013, 22(12):15111517. https://doi.org/10.1517/13543784.2013.833604 PMID: 23978196

[8] Ezewuiro O, Grushko TA, Kocherginsky M, Habis M, Hurteau JA, Mills KA, Hunn J, Olopade OI, Fleming GF, Romero IL. Association of metformin use with outcomes in advanced endometrial cancer treated with chemotherapy. PLoS One, 2016, 11(1):e0147145. https://doi.org/10.1371/journal.pone. 0147145 PMID: 26788855 PMCID: PMC4720394

[9] Xiao Y, Zheng L, Mei Z, Xu C, Liu C, Chu X, Hao B. The impact of metformin use on survival in prostate cancer: a systematic review and meta-analysis. Oncotarget, 2017, 8(59):100449_ 100458. https://doi.org/10.18632/oncotarget.22117 PMID: 29245991 PMCID: PMC5725033

[10] Szaryńska M, Olejniczak A, Kobiela J, Spychalski P, Kmieć Z. Therapeutic strategies against cancer stem cells in human colorectal cancer. Oncol Lett, 2017, 14(6):7653-7668. https:// 
doi.org/10.3892/ol.2017.7261 PMID: 29250169 PMCID: PMC5727596

[11] Zhong S, Wu Y, Yan X, Tang J, Zhao J. Metformin use and survival of lung cancer patients: meta-analysis findings. Indian J Cancer, 2017, 54(1):63-67. https://doi.org/10.4103/ 0019-509X.219582 PMID: 29199666

[12] Kuittinen T, Rovio $P$, Staff $S$, Luukkaala T, Kallioniemi $A$, Grénman S, Laurila M, Mäenpää J. Paclitaxel, carboplatin and 1,25-D3 inhibit proliferation of endometrial cancer cells in vitro. Anticancer Res, 2017, 37(12):6575-6581. https://doi. org/10.21873/anticanres.12114 PMID: 29187432

[13] Makker V, Green AK, Wenham RM, Mutch D, Davidson B, Miller DS. New therapies for advanced, recurrent, and metastatic endometrial cancers. Gynecol Oncol Res Pract, 2017, 4:19. https://doi.org/10.1186/s40661-017-0056-7 PMID: 29214032 PMCID: PMC5712183

[14] Lin JJ, Su JH, Tsai CC, Chen YJ, Liao MH, Wu YJ. 11-epiSinulariolide acetate reduces cell migration and invasion of human hepatocellular carcinoma by reducing the activation of ERK1/2, p38MAPK and FAK/PI3K/AKT/mTOR signaling pathways. Mar Drugs, 2014, 12(9):4783-4798. https://doi.org/ 10.3390/md12094783 PMID: 25222667 PMCID: PMC4178498

[15] Risberg K, Redalen KR, Sønstevold L, Bjørnetrø T, Sølvernes J, Ree AH. Pro-survival responses to the dual inhibition of antiapoptotic Bcl-2 family proteins and mTOR-mediated signaling in hypoxic colorectal carcinoma cells. BMC Cancer, 2016, 16:531. https://doi.org/10.1186/s12885-016-2600-y PMID: 27461218 PMCID: PMC4962454

[16] Deng W, Hua S, Wang Q, He N, Duan C, Han L, Li Q, Lu M, Lv S. A Chinese herbal formula, Yi-Qi-Fu-Sheng, inhibits migration/invasion of colorectal cancer by down-regulating MMP-2/9 via inhibiting the activation of ERK/MAPK signaling pathways. BMC Complement Altern Med, 2013, 13:65. https:// doi.org/10.1186/1472-6882-13-65 PMID: 23506655 PMCID: PMC3617034

[17] Li Y, Xie Y, Cui D, Ma Y, Sui L, Zhu C, Kong H, Kong Y. Osteopontin promotes invasion, migration and epithelialmesenchymal transition of human endometrial carcinoma cell HEC-1A through AKT and ERK1/2 signaling. Cell Physiol Biochem, 2015, 37(4):1503-1512. https://doi.org/10.1159/00 0438518 PMID: 26509489

[18] Jain RK. Tumor angiogenesis and accessibility: role of vascular endothelial growth factor. Semin Oncol, 2002, 29(6 Suppl 16): 3-9. https://doi.org/10.1053/sonc.2002.37265 PMID: 12516032

[19] Papa A, Zaccarelli E, Caruso D, Vici P, Benedetti Panici $P$, Tomao $F$. Targeting angiogenesis in endometrial cancer - new agents for tailored treatments. Expert Opin Investig Drugs, 2016, 25(1):31-49. https://doi.org/10.1517/13543784.2016. 1116517 PMID: 26560489

[20] Qu W, Zhao Y, Wang X, Qi Y, Zhou C, Hua Y, Hou J, Jiang SW. Culture characters, genetic background, estrogen/progesterone receptor expression, and tumorigenic activities of frequently used sixteen endometrial cancer cell lines. Clin Chim Acta, 2019, 489:225-232. https://doi.org/10.1016/j.cca.2018.08.013 PMID: 30107158

[21] Deliloglu-Gurhan I, Tuglu I, Vatansever HS, Ozdal-Kurt F, Ekren H, Taylan M, Sen BH. The effect of osteogenic medium on the adhesion of rat bone marrow stromal cell to the hydroxyapatite. Saudi Med J, 2006, 27(3):305-311. PMID: 16532088

[22] Aydemir I, Özkut MM, Fırat F, Gümürdü A, Sal DH, Erdoğan K, Göker A, Tuğlu Mi. Effects of stem cells applications on oxidative stress and apoptosis during implantation. Asian Pac J Reprod, 2018, 7(5):229-235. https://doi.org/10.4103/2305-0500.241207

[23] Tan LH, Sykes PH, Alkaisi MM, Evans JJ. Cell-like features imprinted in the physical nano- and micro-topography of the environment modify the responses to anti-cancer drugs of endometrial cancer cells. Biofabrication, 2017, 9(1):015017. https://doi.org/10.1088/1758-5090/aa5c9a PMID: 28140336

[24] Kamat AA, Merritt WM, Coffey D, Lin YG, Patel PR, Broaddus R, Nugent E, Han LY, Landen CN Jr, Spannuth WA, Lu C, Coleman RL, Gershenson DM, Sood AK. Clinical and biological significance of vascular endothelial growth factor in endometrial cancer. Clin Cancer Res, 2007, 13(24):7487-7495. https:// doi.org/10.1158/1078-0432.CCR-07-1017 PMID: 18094433

[25] Dinkic C, Jahn F, Zygmunt M, Schuetz F, Rom J, Sohn C, Fluhr H. PARP inhibition sensitizes endometrial cancer cells to paclitaxel-induced apoptosis. Oncol Lett, 2017, 13(4):2847-
2851. https://doi.org/10.3892/ol.2017.5795 PMID: 28454476 PMCID: PMC5403547

[26] Cantrell LA, Zhou C, Mendivil A, Malloy KM, Gehrig PA, BaeJump VL. Metformin is a potent inhibitor of endometrial cancer cell proliferation - implications for a novel treatment strategy. Gynecol Oncol, 2010, 116(1):92-98. https://doi.org/10.1016/ j.ygyno.2009.09.024 PMID: 19822355 PMCID: PMC2789879

[27] Zhang ZJ, Zheng ZJ, Shi R, Su Q, Jiang Q, Kip KE. Metformin for liver cancer prevention in patients with type 2 diabetes: a systematic review and meta-analysis. J Clin Endocrinol Metab, 2012, 97(7):2347-2353. https://doi.org/10.1210/jc.2012-1267 PMID: 22523334

[28] Pierotti MA, Berrino F, Gariboldi M, Melani C, Mogavero A, Negri T, Pasanisi P, Pilotti S. Targeting metabolism for cancer treatment and prevention: metformin, an old drug with multifaceted effects. Oncogene, 2013, 32(12):1475-1487. https:// doi.org/10.1038/onc.2012.181 PMID: 22665053

[29] Zhao Y, Sun H, Feng M, Zhao J, Zhao X, Wan Q, Cai D. Metformin is associated with reduced cell proliferation in human endometrial cancer by inbibiting PI3K/AKT/mTOR signaling. Gynecol Endocrinol, 2018, 34(5):428-432. https://doi.org/10. 1080/09513590.2017.1409714 PMID: 29182407

[30] Giovannucci E, Harlan DM, Archer MC, Bergenstal RM, Gapstur SM, Habel LA, Pollak M, Regensteiner JG, Yee D. Diabetes and cancer: a consensus report. Diabetes Care, 2010, 33(7):1674-1685. https://doi.org/10.2337/dc10-0666 PMID: 20587728 PMCID: PMC2890380

[31] Viollet B, Guigas B, Sanz Garcia N, Leclerc J, Foretz M, Andreelli F. Cellular and molecular mechanisms of metformin: an overview. Clin Sci (Lond), 2012, 122(6):253-270. https:// doi.org/10.1042/CS20110386 PMID: 22117616 PMCID: PMC 3398862

[32] Queiroz EAIF, Puukila S, Eichler R, Sampaio SC, Forsyth HL, Lees SJ, Barbosa AM, Dekker RFH, Fortes ZB, Khaper N. Metformin induces apoptosis and cell cycle arrest mediated by oxidative stress, AMPK and FOXO3a in MCF-7 breast cancer cells. PLoS One, 2014, 9(5):e98207. https://doi.org/10.1371/ journal.pone.0098207 PMID: 24858012 PMCID: PMC4032293

[33] Meireles CG, Pereira SA, Valadares LP, Rêgo DF, Simeoni LA, Guerra ENS, Lofrano-Porto A. Effects of metformin on endometrial cancer: systematic review and meta-analysis. Gynecol Oncol, 2017, 147(1):167-180. https://doi.org/10.1016/j.ygyno.2017. 07.120 PMID: 28760367

[34] Mitsuhashi A, Kiyokawa T, Sato Y, Shozu M. Effects of metformin on endometrial cancer cell growth in vivo: a preoperative prospective trial. Cancer, 2014, 120(19):2986-2995. https:// doi.org/10.1002/cncr.28853 PMID: 24917306

[35] Zhang J, Xu H, Zhou X, Li Y, Liu T, Yin X, Zhang B. Role of metformin in inhibiting estrogen-induced proliferation and regulating $E R \alpha$ and $E R \beta$ expression in human endometrial cancer cells. Oncol Lett, 2017, 14(4):4949-4956. https://doi. org/10.3892/ol.2017.6877 PMID: 29085506 PMCID: PMC 5649558

[36] Jain A, Jahagirdar D, Nilendu P, Sharma NK. Molecular approaches to potentiate cisplatin responsiveness in carcinoma therapeutics. Expert Rev Anticancer Ther, 2017, 17(9):815825. https://doi.org/10.1080/14737140.2017.1356231 PMID: 28705091

[37] Yan XY, Qu XZ, Xu L, Yu SH, Tian R, Zhong XR, Sun LK, Su J. Insight into the role of p62 in the cisplatin resistant mechanisms of ovarian cancer. Cancer Cell Int, 2020, 20:128. https://doi. org/10.1186/s12935-020-01196-w PMID: 32322174 PMCID: PMC7164250

[38] Lin Q, Wang Y, Chen D, Sheng X, Liu J, Xiong H. Cisplatin regulates cell autophagy in endometrial cancer cells via the PI3K/AKT/mTOR signalling pathway. Oncol Lett, 2017, 13(5):3567-3571. https://doi.org/10.3892/ol.2017.5894 PMID: 28521459 PMCID: PMC5431239

[39] Kim YS, Kim KS, Cho CH, Yoon KS, Park HK, Jung MH. Quantitative analysis with atomic force microscopy of cisplatininduced morphological changes in HeLa and Ishikawa cells. J Nippon Med Sch, 2012, 79(5):320-326. https://doi.org/10. 1272/jnms.79.320 PMID: 23123387

[40] Khawaja MR, Nick AM, Madhusudanannair V, Fu S, Hong D, McQuinn LM, Ng CS, Piha-Paul SA, Janku F, Subbiah V, Tsimberidou A, Karp D, Meric-Bernstam F, Lu KH, Naing A. Phase I dose escalation study of temsirolimus in combination with metformin in patients with advanced/refractory cancers. 
Cancer Chemother Pharmacol, 2016, 77(5):973-977. https:// doi.org/10.1007/s00280-016-3009-7 PMID: 27014780 PMCID: PMC5978416

[41] Dang JH, Jin ZJ, Liu XJ, Hu D, Wang J, Luo Y, Li LL. Metformin in combination with cisplatin inhibits cell viability and induces apoptosis of human ovarian cancer cells by inactivating ERK 1/2. Oncol Lett, 2017, 14(6):7557-7564. https:// doi.org/10.3892/ol.2017.7176 PMID: 29344202 PMCID: PMC 5755135

[42] Asik A, Kayabasi C, Ozmen Yelken B, Yılmaz Susluer S, Dogan Sigva ZO, Balcı Okcanoglu T, Saydam G, Biray Avci C, Gunduz C. Antileukemic effect of paclitaxel in combination with metformin in $\mathrm{HL}-60$ cell line. Gene, 2018, 647:213-220. https://doi.org/10.1016/j.gene.2018.01.017 PMID: 29309887
[43] Tseng SC, Huang YC, Chen HJ, Chiu HC, Huang YJ, Wo TY, Weng SH, Lin YW. Metformin-mediated downregulation of p38 mitogen-activated protein kinase-dependent excision repair cross-complementing 1 decreases DNA repair capacity and sensitizes human lung cancer cells to paclitaxel. Biochem Pharmacol, 2013, 85(4):583-594. https://doi.org/10.1016/j.bcp. 2012.12.001 PMID: 23228696

[44] Lengyel E, Litchfield LM, Mitra AK, Nieman KM, Mukherjee A, Zhang Y, Johnson A, Bradaric M, Lee W, Romero IL. Metformin inhibits ovarian cancer growth and increases sensitivity to paclitaxel in mouse models. Am J Obstet Gynecol, 2015, 212(4):479.e1-479.e10. https://doi.org/10.1016/j.ajog.2014. 10.026 PMID: 25446664 PMCID: PMC4387077

\section{Corresponding author}

Isil Aydemir, Assistant Professor, MD, PhD, Department of Histology and Embryology, Faculty of Medicine, Nigde Omer Halisdemir University, 51200 Nigde, Turkey; Phone +90 54247395 56, e-mail: isil_aydemir@yahoo.com

Received: May 25, 2020

Accepted: January 19, 2021 